\title{
Karakteristik Ibu pada Penderita Abortus dan Tidak Abortus di RS Dr. M. Djamil Padang Tahun 2011-2012
}

\author{
Resya I. Noer ${ }^{1}$, Ermawati $^{2}$, Afdal $^{3}$
}

\begin{abstract}
Abstrak
Abortus adalah berakhirnya kehamilan sebelum janin dapat hidup di luar kandungan dengan batasan kehamilan kurang dari 20 minggu atau berat janin kurang dari 500 gram. Tujuan penelitian ini adalah membandingkan hubungan usia ibu, usia kehamilan, pekerjaan dan pendidikan terhadap kejadian abortus dan tidak abortus. Penelitian ini menggunakan desain cross-sectional. Populasi adalah rekam medik seluruh ibu hamil yang menjalani rawat inap di bagian Obstetri dan Ginekologi RS Dr. M. Djamil Padang sejak Januari 2011 sampai Desember 2012. Jumlah sampel sebanyak 272 orang yang diambil dengan teknik simple random sampling. Data diambil dengan cara melihat data sekunder dari rekam medis pasien dan dianalisis menggunakan analisis univariat dan bivariat uji chi-square pada nilai $\mathrm{p}<0,05$. Hasil penelitian menunjukkan bahwa angka kejadian abortus tahun 2011-2012 adalah 5,83\%. Ibu yang mengalami abortus lebih banyak berada di kelompok usia dibawah 20 tahun dan diatas 35 tahun, paritas lebih dari 3 , pernah mengalami abortus sebelumnya, usia kehamilan kurang dari 12 minggu, tidak bekerja dan pendidikan terakhir SD, SLTP dan SLTA dibandingkan dengan ibu yang tidak mengalami abortus. Uji statistik menunjukkan bahwa usia ibu, usia kehamilan, pekerjaan dan pendidikan memengaruhi terjadinya abortus $(p=0,035 ; p=0,000 ; p=0,002$ dan $p=0,043$ ), sedangkan paritas dan riwayat abortus sebelumnya tidak memengaruhi terjadinya abortus ( $p=0,919$ dan $p=0,205)$.
\end{abstract}

Kata kunci: usia ibu, paritas, riwayat abortus, usia kehamilan, pekerjaan ibu, pendidikan ibu, abortus

\begin{abstract}
Abortion is a pregnancy termination before the $20^{\text {th }}$ completed week or weighing less than 500 gram. The objective of this study was to determine the relationship of the age, parity, history of previous abortion, gestational age, mother's occupation and education on abortion and without abortion. The design was comparative study with the cross sectional approach. The population was taken from the medical records of all pregnant women who is hospitalized at the Obstetric and Gynaecology Department in Dr. M. Djamil Hospital during during the period January 2011 to December 2012. The total samples of 272 people were taken by multi-stage random sampling. The data were collected from medical records and analyzed using univariate and bivariate analysis with Chi-Square test at p-value < 0,05. The results are the incidence of abortion at Dr. M. Djamil Hospital during the periode January 2011 to December 2012 is 5.83\%. Pregnant women with abortion were mostly at the age 20 years and above 35 years, parity more than 3, had previous abortions, gestational age less than 12 weeks, does not work and elementary school, junior and senior high as their latest education compared to pregnant women without abortion. Statistical test results showed that maternal age, gestational age, occupation and education can affect the insidence of abortion ( $p=0.035 ; p=0.000$; $p=0.002$ dan $p=0.043$ ). Parity and history of previous abortion don't affect the incidence of abortion ( $p=0.919$ dan $p=0.205)$.
\end{abstract}

Keywords: maternal age, parity, history of previous abortion, gestational age, occupation, education, abortion

Affiliasi penulis: 1. Prodi Profesi Dokter FK UNAND (Fakultas Kedokteran Universitas Andalas Padang), 2. Bagian Obstetri dan
Ginekologi FK UNAND/RS Dr. M. Djamil Padang, 3. Bagian IImu Kesehatan Anak FK UNAND/RS Dr. M. Djamil Padang 
Korespondensi: Resya I. Noer , Email: resyaiyashanoer@gmail.com, Telp: 085274655551

\section{PENDAHULUAN}

Kematian dan kesakitan ibu hamil masih merupakan masalah besar di dunia. Badan Kesehatan Dunia atau World Health Organization (WHO) menyatakan bahwa sekitar 800 wanita meninggal selama kehamilan ataupun komplikasi pada saat melahirkan setiap harinya. Pada tahun 2010, lebih dari 287.000 ibu meninggal saat hamil ataupun bersalin. ${ }^{1}$ Menurut Survey Demografi dan Kesehatan Indonesia (SDKI) tahun 2007 seperti yang dikutip oleh Gustina (2012), angka Kematian lbu (AKI) di Indonesia sebesar 228 per 100.000 kelahiran hidup. $^{2}$

Penyebab utama dari kematian ibu hamil di Indonesia adalah perdarahan $28 \%$, infeksi $11 \%$ dan eklampsia 24\%. Penyebab perdarahan pada ibu hamil adalah abortus, kehamilan ektopik, perdarahan antepartum (plasenta previa dan solusio plasenta), perdarahan postpartum (retensio plasenta, atonia uteri dan trauma kelahiran. ${ }^{3}$

Abortus adalah pengeluaran hasil konsepsi sebelum janin dapat hidup diluar kandungan yang batasannya adalah kehamilan kurang dari 20 minggu atau berat badan janin kurang dari 500 gram. Diperkirakan frekuensi abortus spontan sebesar 1015\%. Di Indonesia, diperkirakan ada 5 juta kehamilan setiap tahun. Dengan demikian, setiap tahun bisa terjadi 500.000-750.000 abortus spontan. ${ }^{4}$ Di RS Dr. M. Djamil, insiden abortus sebanyak 16,5\% dari seluruh persalinan yang terjadi pada tahun 2006 . Angka kejadian abortus pada tahun 2006 ini lebih rendah jika dibandingkan dengan kejadian abortus pada tahun 2004 yaitu sebesar 22,1\%.

Faktor risiko terjadinya abortus meliputi; usia, paritas ibu, riwayat abortus, infeksi selama kehamilan, merokok, pengonsumsian alkohol, kafein, diabetes mellitus, hipertensi, rendahnya sosial ekonomi, toksin seperti arsen dan karbon disulfida, kelainan pada uterus dan lain-lain. ${ }^{6}$ Ada 1\%-10\% malformasi janin diakibatkan oleh paparan obat, bahan kimia, radiasi dan umumnya berakhir dengan abortus., ${ }^{3,7}$ Adapun faktor diatas juga dapat dapat dikelompokkan menjadi tiga yaitu, faktor ibu, faktor plasenta dan faktor janin. Diantara ketiga faktor tersebut, sebanyak $60 \%$ faktor ibu berperan dalam terjadinya abortus, diikuti faktor janin $20 \%$ dan faktor plasenta $15 \%{ }^{8}$

Faktor usia merupakan salah satu faktor yang paling berpengaruh terhadap terjadinya abortus. Abeysena et al menyebutkan bahwa usia ibu yang lebih dari 35 tahun merupakan salah satu faktor risiko dari terjadinya abortus spontan $(\mathrm{OR}=2,98) .{ }^{9}$ Menurut penelitian yang dilakukan Ashikin, dari 230 kasus abortus yang terjadi pada tahun 2006, sebanyak $37,8 \%$ penderita abortus mayoritas berusia 30-34 tahun. $^{5}$ Machonochie et al menyebutkan bahwa kejadian abortus meningkat pada ibu yang berusia 35 39 tahun (OR $(95 \% \quad \mathrm{Cl})=1,75(1,37-2,22))$ dan meningkat lima kali lipat pada ibu yang berusia lebih dari 40 tahun (OR $(95 \% \quad \mathrm{Cl})=5,16(3,54-7,52))^{6}$ Penelitian yang dilakukan oleh Sugiharti, dinyatakan bahwa dari 105 ibu hamil yang mengalami abortus, $58,5 \%$ diantaranya adalah ibu yang berusia dibawah 20 tahun, 17,1\% berusia antara 20-35 tahun, dan $87,5 \%$ berusia diatas 35 tahun. $^{8}$

Faktor lain yang berperan serta terhadap terjadinya abortus adalah paritas. Ashikin dalam penelitiannya menyebutkan bahwa sebanyak sebanyak 24.3\% penderita abortus pada tahun 2006 mempunyai paritas satu. ${ }^{5}$ Penelitian yang dilakukan oleh Gustina menyatakan bahwa dari 70 ibu yang mengalami abortus, 33\% diantaranya mempunyai paritas yang kurang dari 1 dan lebih dari 3 dan 52,9\% mempunyai paritas $1-3{ }^{2}$ Sugiharti menyatakan bahwa 105 ibu hamil yang mengalami abortus, 4,9\% merupakan primipara, 43,8\% multipara dan $33,3 \%$ merupakan grandemultipara. $^{8}$

Riwayat abortus juga merupakan salah satu faktor yang dapat meningkatkan risiko terjadinya abortus pada ibu hamil. Machonochie et al telah menyebutkan risiko abortus akan meningkat pada ibu yang mempunyai riwayat abortus sebelumnya (OR $(95 \% \quad C l)=1,84(1,47-2,31))^{6} \quad$ Gustina menyatakan bahwa sebanyak $17,1 \%$ dari 70 ibu hamil yang mengalami abortus pernah mengalami abortus dan $83,9 \%$ tidak pernah mengalami abortus. ${ }^{2}$

Usia kehamilan saat terjadinya abortus dapat memberi gambaran mengenai penyebab abortus spontan itu sendiri. Diperkirakan $80 \%$ abortus spontan 
terjadi dalam trimester pertama. Sebanyak 60\%-80\% abortus terjadi pada kehamilan 12 minggu atau kurang dan sisanya terjadi pada setelah kehamilan mencapai usia 12 minggu. ${ }^{10}$ Campbell et al menyebutkan bahwa jumlah abortus yang terjadi diketahui akan menurun seiring bertambahnya usia kehamilan, dari $25 \%$ pada 5 hingga 6 minggu pertama kehamilan menjadi $2 \%$ setelah 12 minggu kehamilan. ${ }^{11}$ Tong et al juga menyebutkan bahwa risiko terjadinya abortus spontan akan menurun seiring bertambahnya usia kehamilan, yaitu sebesar 9,4\% saat kehamilan mencapai usia 6 minggu, $2,2 \%$ saat 7 minggu, $1,5 \%$ saat 8 minggu, $0,5 \%$ saat mencapai usia 9 minggu dan $0,7 \%$ saat mencapai usia 10 minggu. ${ }^{12}$

Faktor sosial ekonomi yang berpengaruh terhadap terjadinya abortus adalah pekerjaan ibu dan pendidikan ibu. Gustina menyatakan bahwa $90 \%$ dari ibu hamil yang mengalami abortus merupakan ibu dengan pendidikan rendah. Hal ini dapat terjadi karena pada ibu dengan pendidikan rendah cenderung kurang memperhatikan kesehatan dirinya terutama kehamilannya. ${ }^{2}$ Sugiharti dalam penelitiannya menyebutkan bahwa dari 178 ibu hamil yang mengalami abortus $37,6 \%$ persen diantaranya adalah ibu yang bekerja. Hal ini mungkin disebabkan karena tingkat kelelahan fisik pada ibu yang bekerja lebih tinggi daripada ibu yang tidak bekerja dan dapat memengaruhi kesehatan reproduksi ibu. ${ }^{8}$

Berdasarkan uraian diatas dan belum adanya penelitian tentang perbedaan karakteristik ibu pada penderita abortus dan tidak abortus di RS. Dr. M. Djamil Padang dalam lima tahun terakhir ini, sehingga perlu dilakukan penelitian untuk mengetahui perbedaan karakteristik ibu pada penderita abortus dan tidak abortus di RSUP. Dr. M. Djamil Padang periode Januari 2011-Desember 2012.

\section{METODE}

Jenis penelitian ini merupakan suatu study comparative yang membandingkan antara kelompok ibu hamil dengan abortus dan kelompok ibu hamil tanpa abortus menggunakan pendekatan cross sectional. Populasi dalam penelitian ini adalah seluruh pasien ibu hamil yang menjalani rawat inap di bagian Obstetri dan Ginekologi RS Dr. M. Djamil Padang selama periode Januari 2011 - Desember 2012. Sampel penelitian adalah seluruh pasien ibu hamil yang menjalani rawat inap di bagian Obstetri dan Ginekologi RS Dr. M. Djamil Padang selama periode Januari 2011-Desember 2012 yang memenuhi kriteria inklusi. Jumlah sampel dalam penelitian ini adalah sebanyak 300 orang yang diperoleh berdasarkan rumus sampel minimal. Sampel diambil dengan menggunakan teknik simple random sampling.

Kriteria inklusi meliputi kelompok ibu hamil dengan abortus, yaitu seluruh ibu hamil yang didiagnosis menderita abortus di bagian Obstetri dan Ginekologi RS Dr. M. Djamil Padang selama periode Januari 2011-Desember 2012, dan kelompok ibu hamil tanpa abortus, yaitu ibu hamil trimester I, II dan III yang tidak didiagnosis menderita abortus di bagian Obstetri dan Ginekologi RS Dr. M. Djamil Padang selama periode Januari 2011 sampai Desember 2012. Kriteria eksklusi meliputi seluruh ibu hamil yang tidak memiliki catatan rekam medis lengkap yang memuat data usia ibu, paritas, riwayat abortus, usia kehamilan, pekerjaan, pendidikan dan pasien yang catatan rekam medisnya tidak ditemukan di bagian Rekam Medis RS Dr. M. Djamil Padang.

Variabel dependen dalam penelitian ini adalah abortus. Variabel independen dalam penelitian ini adalah usia ibu, paritas, riwayat abortus sebelumnya, usia kehamilan, pekerjaan dan pendidikan.

Instrumen yang digunakan dalam penelitian ini adalah data rekam medis; check-list yang berisi tentang nomor rekam medis pasien, usia ibu, paritas ibu, riwayat abortus sebelumnya, usia kehamilan, pekerjaan, dan pendidikan; serta alat tulis. Penelitian dilakukan di bagian Rekam Medis RS Dr. M. Djamil Padang pada bulan Oktober 2012-Mei 2013.

Prosedur pengambilan data penelitian ini adalah dengan cara melihat data sekunder dari rekam medis pasien yang didiagnosis abortus dan tidak didiagnosis abortus dengan jumlah 135 sampel untuk setiap masing-masing kelompok pada periode Januari 2011-Desember 2012 kemudian dicatat sesuai dengan data yang dibutuhkan dalam penelitian.

Cara pengolahan data yang dilakukan yaitu memastikan data yang telah diperoleh adalah benar dan lengkap, memberikan kode pada setiap data 
variabel yang telah terkumpul, dilakukan pemindahan data ke dalam master tabel dan diolah secara komputerisasi. Analisis data terdiri dari analisis univariat dan bivariat. Analisis bivariat dilakukan dengan menggunakan uji statistik chi square dengan derajat kemaknaan $p<0,05$.

\section{HASIL}

Angka Kejadian Abortus di RS. Dr. M. Djamil Padang

Jumlah pasien abortus yang ditemukan adalah sebanyak 200 (5,83\%) pasien dari 3431 ibu hamil yang dirawat selama periode Januari 2011-Desember 2012. Kejadian abortus terbanyak terjadi pada tahun 2011 yaitu sebanyak 112 kasus abortus dari 1654 ibu hamil yang dirawat atau sekitar 6,77\%, sedangkan pada tahun 2012, terdapat 88 kasus abortus dari 1777 ibu hamil yang dirawat atau sekitar 4,95\%.

\section{Perbandingan Usia Ibu pada Penderita Abortus dan Tidak Abortus}

Perbandingan usia ibu pada penderita abortus dan tidak abortus pada periode Januari 2011 Desember 2012 dapat dilihat dalam tabel berikut.

Tabel 1. Perbandingan usia ibu pada penderita abortus dan tidak abortus

\begin{tabular}{lcccc}
\hline \multirow{2}{*}{ Usia } & \multicolumn{2}{c}{ Abortus } & Total & \multirow{2}{*}{ Nilai p } \\
\cline { 2 - 4 } & Ya & Tidak & $\mathbf{n}$ & \\
\hline <20Tahun & 6 & 4 & 10 & \\
20-35 tahun & 89 & 108 & 199 & 0.035 \\
$>35$ tahun & 41 & 24 & 63 & \\
\hline Total & 136 & 136 & 272 & \\
\hline
\end{tabular}

Pada Tabel 1 diatas, dapat dilihat bahwa ibu yang mengalami abortus lebih banyak berada di kelompok usia dibawah 20 tahun dan diatas 35 tahun dibandingkan dengan ibu yang tidak mengalami abortus. Dari hasil uji chi-square, didapatkan nilai $p=$ $<0.05$, artinya usia ibu memengaruhi abortus.

\section{Perbandingan Paritas pada Penderita Abortus dan Tidak Abortus}

Perbandingan paritas pada penderita abortus dan tidak abortus pada periode Januari 2011Desember2012 dapat dilihat dalam tabel berikut.
Tabel 2. Perbandingan paritas pada penderita abortus dan tidak abortus

\begin{tabular}{ccccc}
\hline \multirow{2}{*}{ Paritas } & \multicolumn{2}{c}{ Abortus } & Total & \multirow{2}{*}{ Nilai p } \\
\cline { 2 - 3 } & Ya & Tidak & $\mathbf{n}$ & \\
\hline Paritas 0 & 42 & 42 & 86 & \\
Paritas 1-3 & 79 & 81 & 160 & 0,919 \\
Paritas $>3$ & 15 & 13 & 28 & \\
\hline Total & 136 & 136 & 272 & \\
\hline
\end{tabular}

Tabel 2 memperlihatkan bahwa ibu yang mengalami abortus lebih banyak berada di kelompok paritas lebih dari 3 dibandingkan dengan ibu yang tidak mengalami abortus. Hasil uji chi-square, didapatkan nilai $p=>0,05$, artinya paritas tidak memengaruhi terjadinya abortus.

\section{Perbandingan Riwayat Abortus Sebelumnya pada Penderita Abortus dan Tidak Abortus}

Perbandingan riwayat abortus sebelumnya pada penderita abortus dan tidak abortus pada periode Januari 2011-Desember 2012 dapat dilihat dalam tabel berikut.

Tabel 3. Perbandingan riwayat abortus sebelumnya pada penderita abortus dan tidak abortus

\begin{tabular}{ccccc}
\hline \multirow{2}{*}{$\begin{array}{c}\text { Riwayat } \\
\text { Abortus }\end{array}$} & \multicolumn{2}{c}{ Abortus } & Total & \multirow{2}{*}{ Nilai $\mathbf{p}$} \\
\cline { 2 - 3 } & Ya & Tidak & $\mathbf{n}$ & \\
\hline Pernah & 21 & 14 & 35 & 0,205 \\
Tidak pernah & 115 & 122 & 237 & \\
\hline Total & 136 & 136 & 272 & \\
\hline
\end{tabular}

Tabel 3 di atas memperlihatkan bahwa ibu yang pernah mengalami abortus sebelumnya lebih banyak berada pada kelompok ibu yang mengalami abortus dibandingkan dengan ibu yang tidak mengalami abortus. Hasil uji chi-square, didapatkan nilai $p>0,05$, artinya riwayat abortus sebelumnya tidak memengaruhi terjadinya abortus.

\section{Perbandingan Usia Kehamilan pada Penderita Abortus dan Tidak Abortus}

Perbandingan usia kehamilan pada penderita abortus dan tidak abortus pada periode Januari 2011 . Desember 2012 dapat dilihat dalam tabel berikut.

Pada Tabel 4 di atas, dapat dilihat bahwa ibu yang mengalami abortus lebih banyak memiliki usia 
kehamilan dibawah 12 minggu dibandingkan dengan ibu yang tidak mengalami abortus. Dari hasil uji chisquare, didapatkan nilai $p=<0,05$, artinya terdapat usia kehamilan memengaruhi terjadinya abortus.

Tabel 4. Perbandingan usia kehamilan pada penderita abortus dan tidak abortus

\begin{tabular}{ccccc}
\hline \multirow{2}{*}{$\begin{array}{c}\text { Usia } \\
\text { Kehamilan }\end{array}$} & \multicolumn{2}{c}{ Abortus } & Total & \multirow{2}{*}{ Nilai $\mathbf{p}$} \\
\cline { 2 - 4 } & $\mathbf{} \mathbf{a}$ & Tidak & $\mathbf{n}$ & \\
\hline$<12$ minggu & 103 & 14 & 117 & 0,000 \\
$\geq 12$ minggu & 33 & 122 & 155 & \\
\hline Total & 136 & 136 & 272 & \\
\hline
\end{tabular}

Perbandingan Pekerjaan Ibu pada Penderita Abortus dan Tidak Abortus

Perbandingan pekerjaan ibu pada penderita abortus dan tidak abortus pada periode Januari 2011Desember 2012 dapat dilihat dalam tabel berikut.

Tabel 5. Perbandingan pekerjaan ibu pada penderita abortus dan tidak abortus

\begin{tabular}{ccccc}
\hline \multirow{2}{*}{ Pekerjaan } & \multicolumn{2}{c}{ Abortus } & Total & \multirow{2}{*}{ Nilai $\mathbf{p}$} \\
\cline { 2 - 4 } & Ya & Tidak & $\mathbf{n}$ & \\
\hline Bekerja & 17 & 38 & 55 & 0,000 \\
Tidak Bekerja & 119 & 98 & 217 & \\
\hline Total & 136 & 136 & 272 & \\
\hline
\end{tabular}

Tabel 5 di atas, dapat dilihat bahwa dari perbandingan pekerjaan pada penderita abotus dan tidak abortus didapatkan bahwa ibu yang mengalami abortus lebih banyak tidak bekerja dibandingkan dengan ibu yang tidak mengalami abortus. Hasil uji chi-square, didapatkan nilai $p=<0,05$, artinya pekerjaan memengaruhi terjadinya abortus.

\section{Perbandingan Pendidikan Ibu pada Penderita Abortus dan Tidak Abortus}

Perbandingan pendidikan ibu pada penderita abortus dan tidak abortus pada periode Januari 2011 Desember 2012 dapat dilihat dalam tabel berikut.

Pada Tabel 6, dapat dilihat bahwa ibu yang mengalami abortus lebih banyak memiliki pendidikan terakhir SD, SLTP dan SLTA dibandingkan dengan ibu yang tidak mengalami abortus. Dari hasil uji chisquare, didapatkan nilai $p=<0,05$.
Tabel 6. Perbandingan pendidikan ibu pada penderita abortus dan tidak abortus

\begin{tabular}{lcccc}
\hline \multirow{2}{*}{ Pendidikan } & \multicolumn{2}{c}{ Abortus } & Total & \multirow{2}{*}{ Nilai $\mathbf{p}$} \\
\cline { 2 - 3 } & Ya & Tidak & $\mathbf{n}$ & \\
\hline SD & 13 & 8 & 21 & \\
\hline SLTP & 28 & 19 & 47 & \multirow{2}{*}{0.043} \\
\hline SLTA & 81 & 80 & 161 & \\
\hline Universitas & 14 & 29 & 43 & \\
\hline Total & 136 & 136 & 272 \\
\hline
\end{tabular}

\section{PEMBAHASAN}

\section{Angka Kejadian Abortus di RS Dr. M. Djamil Padang}

Berdasarkan penelitian yang telah dilakukan, diperoleh angka kejadian abortus pada tahun 2011 dan 2012 di RS Dr. M. Djamil adalah 200 kasus dari 3431 ibu hamil dirawat atau sebesar 5,83\%. Pada tahun 2011, angka kejadian abortus diperoleh sebesar $6,77 \%$, sedangkan pada tahun 2012, diperoleh angka kejadian abortus sebesar 4,95\%. Penelitian ini menunjukkan bahwa terjadi penurunan insiden abortus pada tahun 2011 dan 2012. Angka kejadian abortus pada tahun 2011 dan 2012 ini lebih rendah dibandingkan angka kejadian abortus pada tahun 2006, yaitu sebesar $16,5 \% .^{5}$ Penelitian yang dilakukan Gustina menyatakan bahwa angka kejadian abortus di RSUD Soreang Bandung sebesar 2,24\% dari seluruh ibu hamil yang berkunjung dan dirawat (9909 pasien). ${ }^{2}$ Hasil penelitian yang dilakukan Wong menyebutkan bahwa prevalensi abortus spontan di RSUP H. Adam Malik Medan pada tahun 2011 adalah 7,1\%. ${ }^{13}$

Adanya perbedaan angka kejadian ini dapat dipengaruhi oleh beberapa faktor seperti keadaan sosial ekonomi, perbedaan karakteristik demografi dari populasi, perbedaan kriteria penentuan diagnosis, dan lain-lain. ${ }^{5}$ Perbedaan tersebut juga dipengaruhi oleh adanya perbedaan jumlah ibu hamil yang berkunjung dan dirawat di RS Dr. M. Djamil Padang pada tahun 2011 dan 2012

\section{Perbandingan Usia Ibu pada Penderita Abortus dan Tidak Abortus}

Pada penelitian ini, diperoleh bahwa ibu yang mengalami abortus sebanyak $60 \%$ berada di kelompok usia dibawah 20 tahun dan 63,1\% berada di 
kelompok usia lebih dari 35 tahun. Hasil penelitian ini sejalan dengan teori yang menyatakan bahwa usia ibu dibawah 20 tahun dan diatas 35 tahun dapat meningkatkan risiko terjadinya abortus pada ibu hamil.

Berdasarkan hasil uji chi-square, didapatkan nilai $p=0,03$ yang membuktikan bahwa usia memengaruhi terjadinya abortus. Hasil penelitian ini sejalan dengan hasil penelitian yang dilakukan oleh Gustina $^{2}$ dan Ashikin ${ }^{5}$ yaitu terdapat hubungan yang bermakna antara usia ibu dengan kejadian abortus dengan $p<0,05$. Arsana et al dalam penelitiannya juga menyatakan bahwa didapatkan hubungan yang bermakna antara usia ibu dibawah 20 tahun dan usia ibu diatas 35 tahun dengan kejadian abortus dengan $\mathrm{p}$ $<0,05$. $^{14}$

Hasil penelitian ini sejalan dengan kepustakaan bahwa usia ibu dibawah 20 tahun dan diatas 35 tahun berisiko tinggi untuk melahirkan. Usia diantara 20 dan 35 tahun dianggap sebagai usia yang ideal bagi seorang wanita untuk hamil. Kehamilan ibu dengan usia dibawah 20 tahun berpengaruh kepada kematangan fisik dan mental dalam menghadapi kehamilan. ${ }^{15}$ Usia ibu dibawah 35 tahun berisiko tinggi untuk mengalami penyulit dalam kehamilan, seperti sering mengalami anemia, keguguran, preeklampsia, gangguan tumbuh kembang janin, prematuritas, Berat Badan Lahir Rendah (BBLR) dan lain-lain. Usia diatas 35 tahun juga meningkatkan risiko terjadinya abortus. Ruhmiatie mengemukakan beberapa teori yang berkaitan dengan risiko tinggi kehamilan untuk ibu dengan usia diatas 35 tahun, yaitu terjadinya penurunan fungsi reproduksi, ibu hamil dengan usia 35 tahun dua kali lebih rawan untuk menderita tekanan darah tinggi dan diabetes mellitus pada saat pertama kali hamil dan tingginya risiko kelainan genetik pada bayi yang dikandungnya. ${ }^{16}$

\section{Perbandingan Paritas pada Penderita Abortus dan Tidak Abortus}

Hasil analisis data menunjukkan bahwa ibu yang mengalami abortus lebih banyak memiliki paritas lebih dari 3 sebanyak 53,6\%, dibandingkan ibu yang tidak mengalami abortus. Penelitian yang dilakukan Ashikin menunjukkan bahwa kejadian abortus lebih banyak pada ibu multipara yaitu sebanyak $76, \%{ }^{5}$
Wong dalam penelitiannya juga menyebutkan bahwa kejadian abortus di RSUP Dr. H. Adam Malik Medan paling banyak dialami oleh ibu multipara $(59,4 \%) .{ }^{13}$ Sugiharti dalam penelitiannya menyebutkan bahwa $43,7 \%$ dari ibu yang mengalami abortus merupakan ibu dengan multipara, 4,9\% merupakan primipara dan $33,3 \%$ merupakan grandemultipara. Hal ini sesuai dengan teori bahwa semakin tinggi paritas ibu, maka semakin tinggi risiko untuk mengalami abortus. Ibu dengan paritas tinggi mengalami penurunan fungsi produksi dan dapat mengalami trauma jalan lahir yang mengakibatkan serviks menjadi tidak kompeten dan mudah terbuka sehingga tidak mampu mempertahankan hasil konsepsi untuk kehamilan berikutnya sehingga berisiko terjadinya abortus. $^{8}$

Berdasarkan hasil uji statistik, didapatkan nilai $p=0,919$. Ini berarti bahwa paritas tidak memengaruhi terjadinya abortus. Hasil penelitian ini sejalan dengan hasil penelitian yang dilakukan Gustina yaitu tidak terdapat hubungan yang bermakna antara paritas dengan kejadian abortus. Hasil uji statistik ini tidak sesuai dengan teori yang menyatakan bahwa paritas memengaruhi terjadinya abortus. ${ }^{2}$

Hasil penelitian ini berbeda dengan hasil penelitian yang dilakukan oleh Arsana et al yang menyebutkan bahwa terdapat hubungan yang bermakna antara paritas dengan kejadian abortus $(p=$ 0,01). ${ }^{14}$ Sugiharti dalam penelitiannya juga menyebutkan bahwa terdapat hubungan yang bermakna antara paritas dengan kejadian abortus ( $p=$ 0,000). ${ }^{8}$ Adanya perbedaan hasil penelitian ini mungkin disebabkan oleh beberapa faktor seperti adanya perbedaan waktu dan tempat penelitian dan adanya perbedaan metodologi penelitian yang dipakai. Perbedaan hasil penelitian ini juga menunjukkan bahwa paritas belum tentu memengaruhi terjadinya abortus.

\section{Perbandingan Riwayat Abortus Sebelumnya pada Penderita Abortus dan Tidak Abortus}

Hasil penelitian ini menunjukkan bahwa riwayat abortus sebelumnya lebih banyak terdapat pada kelompok ibu yang mengalami abortus, sebanyak $60 \%$, dibandingkan ibu yang tidak mengalami abortus. 
Pandey et al menyebutkan bahwa risiko abortus meningkat sebanyak $24 \%$ apabila ibu telah mengalami abortus sebanyak dua kali sebelumnya, $30 \%$ apabila telah mengalami tiga kali, dan $40 \%$ apabila telah mengalami empat kali berturut-turut. ${ }^{17}$ Machonochie et al juga menyebutkan bahwa riwayat abortus sebelumnya merupakan salah satu faktor yang dapat meningkatkan risiko terjadinya abortus, khususnya pada trimester pertama. ${ }^{6}$

Berdasarkan hasil uji statistik, diperoleh nilai $p$ $=0,205$, yang artinya tidak terdapat riwayat abortus sebelumnya tidak memengaruhi terjadinya abortus. Hasil penelitian ini sejalan dengan penelitian Gustina yang menyebutkan bahwa tidak terdapat hubungan yang bermakna antara riwayat abortus dengan kejadian abortus. $^{2}$

Hasil penelitian ini berbeda dengan penelitian yang dilakukan oleh Arsana et al yang menyebutkan bahwa terdapat hubungan yang bermakna antara riwayat abortus dengan kejadian abortus $(p=0,02)$. Adanya perbedaan hasil penelitian ini kemungkinan disebabkan oleh beberapa faktor seperti adanya perbedaan waktu dan tempat penelitian dan adanya perbedaan metodologi penelitian yang dipakai. Selain itu, perbedaan hasil penelitian ini juga menunjukkan bahwa riwayat abortus sebelumnya belum tentu memengaruhi terjadinya abortus pada ibu hamil. ${ }^{14}$

\section{Perbandingan Usia Kehamilan pada Penderita Abortus dan Tidak Abortus}

Pada penelitian ini, diperoleh ibu dengan usia kehamilan kurang dari 12 minggu lebih banyak mengalami abortus dibandingkan dengan ibu dengan usia kehamilan lebih dari 12 minggu. Pada penelitian ini juga diperoleh bahwa ibu yang tidak mengalami abortus dengan usia kehamilan lebih dari 12 minggu lebih banyak dari ibu dengan usia dibawah 12 minggu. Hasil penelitian ini sesuai dengan teori yang menyatakan bahwa sebagian besar kejadian abortus terjadi pada trimester pertama. Sekitar 50\% kelainan kariotip kromosom terjadi pada trimester pertama. Insiden kelainan kromosom tersebut akan menurun seiring dengan bertambahnya usia kehamilan. Kelainan kromosom yang terjadi paling sering adalah autosomal trisomi atau monosomy $\mathrm{X}^{2}$
Berdasarkan hasil uji statistik, diperoleh nilai $p$ $=0,000$ yang artinya usia kehamilan memengaruhi terjadinya abortus. Hasil penelitian ini sesuai dengan teori yang menyatakan bahwa diperikirakan $80 \%$ abortus terjadi pada trimester pertama. Makrydimas et al dalam penelitiannya yang berjudul Fetal loss following ultrasound diagnosis of a live fetus at 6-10 weeks of gestation menyebutkan bahwa kejadian abortus menurun seiring bertambahnya usia kehamilan, yaitu dari $10 \%$ pada kehamilan 6 minggu, kemudian menjadi 3\% pada usia kehamilan 10 minggu dan kejadian abortus meningkat 2,6 kali lebih tinggi pada wanita yang mempunyai riwayat perdarahan pervaginam selama kehamilan dibandingkan dengan wanita yang tidak mempunyai riawayat perdarahan pervaginam. Makrydimas et al juga menemukan bahwa terdapatnya hubungan antara usia kehamilan dengan terjadinya abortus dengan nilai $p=0,04$. $^{18}$

Hasil penelitian ini juga berkaitan dengan teori yang menyatakan bahwa paling sedikit 50\% kejadian abortus spontan terjadi karena adanya kelainan sitogenetik pada trimester pertama. Kelainan sitogenetik yang timbul dapat berupa trisomi autosom. Triploidi juga ditemukan pada 16\% kejadian abortus, dimana terjadi fertilisasi ovum normal haploid oleh dua sperma sebagai mekanisme patologi primer. Munculnya kelainan sitogenetik pada janin ini dapat memicu terjadinya abortus dan berhubungan dengan bertambahnya usia ibu. Insiden trisomi meningkat seiring bertambahnya usia ibu.

\section{Perbandingan Pekerjaan Ibu pada Penderita Abortus dan Tidak Abortus}

Pada penelitian ini diperoleh $87,5 \%$ ibu yang mengalami abortus tidak bekerja dan $12,5 \%$ ibu yang mengalami abortus bekerja. Hasil analisis data juga menunjukkan ibu yang bekerja lebih banyak pada kelompok ibu yang tidak mengalami abortus dibandingkan dengan ibu yang mengalami abortus. Ibu yang tidak bekerja cenderung melakukan banyak aktivitas di rumah dibandingkan dengan ibu yang bekerja. Pekerjaan rumah yang telalu berat dapat berisiko terhadap kehamilan ibu sehingga tingkat kelelahan fisik pada ibu yang tidak bekerja lebih tinggi dibandingkan ibu yang bekerja. Selain itu, ibu yang 
bekerja dapat memiliki akses yang lebih baik dan bagus terhadap berbagai informasi, termasuk informasi kesehatan. ${ }^{19}$

Berdasarkan hasil uji statistik, diperoleh nilai $p$ $=0,002$ yang artinya pekerjaan memengaruhi terjadinya abortus. Machonochie et al menyebutkan bahwa tidak terdapat bukti yang menyatakan hubungan antara pekerjaan dengan kejadian abortus. ${ }^{6}$ Hasil penelitian yang dilakukan oleh Sugiharti menyebutkan bahwa ibu yang bekerja mempunyai kemungkinan mengalami abortus 2,128 kali dibandingkan ibu yang tidak bekerja. $^{8}$ Adanya perbedaan hasil penelitian ini kemungkinan disebabkan oleh beberapa faktor seperti adanya perbedaan waktu dan tempat penelitian dan adanya perbedaan metodologi penelitian yang dipakai. Selain itu, perbedaan hasil penelitian ini juga menunjukkan bahwa pekerjaan ibu belum tentu memengaruhi terjadinya abortus.

\section{Perbandingan Pendidikan lbu pada Penderita Abortus dan Tidak Abortus}

Pada penelitian ini diperoleh bahwa ibu yang mengalami abortus lebih banyak memiliki pendidikan terakhir SD, SLTP dan SLTA, yaitu sebanyak 61,9\%, $59,6 \%$ dan $50,3 \%$, dibandingkan dengan ibu yang tidak mengalami abortus. Penelitian yang dilakukan Gustina menyebutkan bahwa sebanyak $90 \%$ ibu yang mengalami abortus adalah ibu yang berpendidikan rendah dan sebanyak $10 \%$ berpendidikan tinggi. $^{2}$

Berdasarkan hasil uji statistik, diperoleh nilai $p$ $=0,043$ yang artinya bahwa pendidikan memengaruhi terjadinya abortus. Hasil penelitian ini sesuai dengan hasil penelitian yang dilakukan oleh Widyastuti yang menyatakan bahwa terdapat hubungan yang bermakna antara pendidikan ibu dengan kejadian abortus. $^{20} \mathrm{Hal}$ ini sesuai dengan kepustakaan yang menyebutkan bahwa ibu dengan pendidikan tinggi cenderung lebih memperhatikan dan memantau kondisi kehamilannya serta lebih aktif dalam mengakses berbagai informasi seputar kesehatan, khususnya mengenai kehamilan dan komplikasi. ${ }^{19}$

Penelitian yang dilakukan Gustina menyatakan bahwa tidak terdapat hubungan yang bermakna antara pendidikan dan kejadian abortus. ${ }^{2}$ Adanya ketidaksesuaian hasil penelitian ini kemungkinan disebabkan oleh beberapa faktor seperti adanya perbedaan waktu dan tempat penelitian dan adanya perbedaan metodologi penelitian yang dipakai. Selain itu, perbedaan hasil penelitian ini juga menunjukkan pendidikan belum tentu memengaruhi terjadinya abortus.

\section{KESIMPULAN}

Umur, usia kehamilan, pekerjaan dan pendidikan memengaruhi terjadinya abortus $(p<0,05)$ dan paritas dan riwayat abortus sebelumnya tidak memengaruhi terjadinya abortus $(p>0,05)$

\section{DAFTAR PUSTAKA}

1. WHO. Maternal mortality. 2012 (diunduh 25 Februari 2013). Tersedia dari: URL : HYPERLINK http://www.who.int/mediacentre/factsheets/fs348/e n/index.html\#.

2. Gustina F. Hubungan karakteristik ibu dengan kejadian abortus di RSUD soerang kabupaten bandung periode Januari 2008-Desember 2011 (skripsi). Jakarta: Universitas Pembangunan Nasional "Veteran"; 2012.

3. Prawirohardjo S. Ilmu kebidanan. Edisi ke-4. Jakarta: Yayasan Bina Pustaka Sarwono Prawirohardjo; 2010. hlm. 459-74.

4. Azhari. Masalah abortus dan kesehatan reproduksi perempuan. Palembang: Fakultas Kedokteran Universitas Sriwijaya; 2002.

5. Ashikin N. Hubungan paritas dan usia ibu terhadap terjadinya abortus di RS. Dr. M. Djamil Padang tahun 2006 (skripsi). Padang: Universitas Andalas; 2007.

6. Maconochie N, Doyle P, Prior S, Simmons R. Risk factors for first trimester miscarriage-results from a UK population-based case-control study. BJOG An international Journal of Obsetrics and Gynaecology. 2006:170-86.

7. Cunningham FG, Leveno KJ, Bloom SL, Hauth JC, Gilstrap III L, Wenstrom KD. Williams Obstetrics. 23rd ed. United States of America: The McGrawHill Companies Inc; 2010. p215-33. 
8. Sugiharti RK. Analisa faktor-faktor yang mempengaruhi kejadian abortus di RSIA Amanah Sumpiuh Kelurahan Kebokura, Kecamatan Sumpiuh, Kabupaten Banyumas (karya tulis ilmiah). Surakarta: Universitas Sebelas Maret; 2011.

9. Abeysena C, Jayawardana $P$, Seneviratne DA. Risk factor for spontaneous abortion. Journal of The College of Community Physicians of Sri Lanka. 2009:14-9.

10. Stovall TG. Early pregnancy loss and ectopic pregnancy. Dalam: Jonathan S. Berek, editor (penyunting). Novak's Gynecology. Edisi ke-13. Philadelphia:Lippincott Williams and Wilkins; 2002. hlm.501-10.

11. Campbell S, Monga A. Gynaecology by ten teachers. Edisi ke-18. London: Hodder Arnold; 2002.

12. Tong S, Kaur A, Walker SP, Bryant V, Onwude $\mathrm{JL}$, Permezel M. Miscarriage risk for asymptomatic women after a normal first-trimester prenatal visit. 2008 (diunduh 24 Februari 2013). Tersedia dari: URL: HYPERLINK http://www.ncbi.nlm.nih.gov/ pubmed/18310375

13. Wong SH. Prevalensi abortus di RSUP Haji Adam Malik Medan (karya tulis ilmiah). Medan: Universitas Sumatera Utara; 2011.

14. Arsana IW, Ambarsari, Setijowati AN. Hubungan faktor-faktor resiko dengan terjadinya abortus spontan di RSUD Dr. Saiful Anwar periode Januari-Desember 2003. Malang: Universitas Brawijaya; 2004.
15. Sinaga E. Hubungan karakteristik ibu hamil dengan kejadian abortus di puskesmas jorlang huluan kecamatan Pematang sidamanik kaupaten simalungun tahun 2012. Jurnal Darma Agung. 2012:1-10

16. Ruhmiatie AN, Sumami, Sumini NL. Hubungan usia ibu hamil dengan kejadian abortus di rumah sakit Roemani muhammadiyah semarang tahun 2009. 2010 (diunduh 13 Maret 2013). Tersedia dari: URL: HYPERLINK http://digilib.unimus.ac.id/ download.php?id $=5572$

17. Pandey MK, Rani R, Agrawal S. An update in recurremt spontaneous abortion. Arch Gynecol Obstet. 2003:95-108.

18. Makrydimas G, Sebiree NJ, Lolis D, Vlassis N, Nicolaides $\mathrm{KH}$. Fetal loss following ultrasound diagnosis of a live fetus at 6-10 weeks of gestation. Ultrasound Obstetric Gynecology. 2003:368-72.

19. Destira D. Faktor-faktor yang berhubungan dengan tingkat pemahaman ibu hamil terhadap pesan antenatal care yang terdapat di dalam buku KIA (artikel ilmiah). Semarang: Universitas Diponegoro; 2010.

20. Widyastuti Y. Faktor- faktor yang berhubungan dengan kejadian abortus di ruang kebidanan rumah sakit Muhammadiyah Palembang tahun 2008. 2008 (diunduh 14 Maret 2013). Tersedia dari: URL: HYPERLINK http://www.docstoc.com/ docs/74161935/Faktor--Faktor-yang-Berhubungandengan-Kejadian-Abortus-DiRuang-KebidananRumah-Sakit--Muhammadiyah-Palembang-Tahun$\underline{2009}$ 